Original Research Paper

\title{
Peningkatan Asuhan Kemandirian Penggunaan Tanaman Obat Pada Kader PKK di Dusun Pucung Kranggan II Berbah Sleman Yogyakarta
}

\author{
Arde Toga Nugraha ${ }^{1}$, Asih Triastuti ${ }^{1}$ \\ ${ }^{I}$ Department of Pharmacy, University Islam Indonesia, Sleman, Indonesia;
}

https://doi.org/10.29303/jpmpi.v3i2.842

Sitasi: Nugraha, A. T \& Triastuti, A. (2021). Peningkatan Asuhan Kemandirian Penggunaan Tanaman Obat Pada Kader PKK di Dusun Pucung Kranggan II Berbah Sleman Yogyakarta. Jurnal Pengabdian Magister Pendidikan IPA, 4(3)

\author{
Article history \\ Received: 23 Juli 2021 \\ Revised: 31 Agustus 2021 \\ Accepted: 4 September 2021 \\ *Corresponding Author: Asih \\ Triastuti, University Islam \\ Indonesia, Sleman, Indonesia; \\ Email: Asih.triastuti@uii.ac.id
}

\begin{abstract}
This service activity aims to provide independent care for the use of medicinal plants and traditional medicines as a promotional and preventive effort, which is beneficial for the efficiency and effectiveness of families in maintaining the family health. Independent care is built in the form of a cadre of TAMAWA (Tanam-Manfaat-Waspada/Grow-Use-Alert) frameworks of medicinal plants and traditional medicines, the participants of which are PKK in the village of Pucung Kranggan II. The TAMAWA cadres were formed in each neighbourhood association /RT, with four members per RT. The TAMAWA framework was formed and guided by a community service team, in collaboration with the Center for Herbal Medicine Study (PSOH UII) of the Department of Pharmacy, Universitas Islam Indonesia through several activities, including training in traditional medicinal/medicinal plants, training in traditional medicinal recipes, and the built of a family medicinal plant garden (TOGA). The output of this service is the production of a smartbook for TAMAWA cadres containing the types, benefits, usage preparations, drug interactions and side effects of medicinal plants/traditional medicines and the built of TOGA gardens in each RT in the village. Other outputs have also been produced, such as information media in the form of videos and brochures. It is hoped that this service program will increase public knowledge of medicinal plants/traditional medicines. Also, it is hoped that the community will be more independent and empowered to manage daily health.
\end{abstract}

Keywords: TAMAWA cadre; Promotion and Prevention; TOGA gardens.

\section{Pendahuluan}

Konsep sehat merupakan "keadaan yang sempurna baik fisik, mental maupun sosial, tidak hanya terbebas dari penyakit atau kelemahan/cacat" (WHO, 1948) Pembangunan kesehatan bertujuan untuk meningkatkan kesadaran, kemauan dan kemampuan seluruh masyarakat untuk hidup sehat guna mencapai derajat kesehatan masyarakat yang setinggi-tingginya sebagaimana diatur dalam Undang-Undang Nomor 17 RPJPN 2005-2025 (Bappenas, 2007). Salah satu pilar utama pelaksanaan "Indonesia Sehat" adalah dengan penerapan paradigma kesehatan melalui pendekatan keluarga. Penerapan paradigma sehat dilakukan dengan strategi penguatan upaya promotif dan preventif, serta pemberdayaan masyarakat (KeMenKes, 2016) dengan berfokus pada penguatan keluarga sebagai unit terkecil komunitas dalam masyarakat.

Arah kebijakan kesehatan yang memperkuat upaya peningkatan kesehatan dan pencegahan penyakit serta pemberdayaan masyarakat dapat dipenuhi salah satunya oleh pelayanan kesehatan tradisional yang berorientasi pada upaya menyehatkan yang sakit dan mempertahankan yang sehat sekaligus meningkatkan kualitas hidup seseorang. Sejalan 
dengan Peraturan Pemerintah Nomor 103 tahun 2014 tentang Pelayanan Kesehatan Tradisional pada pasal 70 menyatakan bahwa masyarakat dapat melakukan perawatan kesehatan secara mandiri dan benar dengan memanfaatkan Taman Obat Keluarga (TOGA) dan Keterampilan. Diharapkan masyarakat dapat melakukan kunjungan ke Puskesmas untuk konsultasi masalah kesehatannya dalam rangka meningkatkan upaya promotif dan preventif (Kemenkes, 2016).

Terbatasnya kapasitas promosi kesehatan di daerah dan kurangnya tenaga promosi kesehatan mengakibatkan tidak maksimalnya pelaksanaan promosi kesehatan dan pemberdayaan masyarakat, terutama tentang tanaman obat/ obat tradisional. Berdasarkan laporan Rifaskes 2011, diketahui bahwa jumlah tenaga penyuluh kesehatan masyarakat di Puskesmas hanya 4.144 orang di seluruh Indonesia. Tenaga tersebut tersebar di 3.085 Puskesmas (34,4\%). Rata-rata tenaga promosi kesehatan di Puskesmas sebanyak 0,46 per Puskesmas. Itu pun hanya $1 \%$ yang memiliki basis pendidikan/pelatihan promosi kesehatan (KeMenKes, 2017). Oleh karena itu diperlukan suatu asuhan mandiri yang melibatkan partisipasi masyarakat terutama perempuan, untuk memaksimalkan promosi kesehatan, terutama di tingkat terkecil yaitu RW/ Dusun melalui pembentukan kader TAMAWA.

Tujuan kegiatan ini adalah untuk membangun masyarakat yang sehat jasmani dan rohani, berpendidikan, dan berbudaya sehat. Mitra pada pengabdian ini adalah masyarakat dusun Pucung-Umbulsari yang dusunnya terletak $24 \mathrm{~km}$ dari Kampus UII. Selama ini penggunaan obat tradisional di RW 32 Dusun Pucung masih sangat terbatas karena masih rendahnya tingkat pengetahuan tentang manfaat dan cara penggunaan tanaman obat. Selain itu, kewaspadaan masyarakat akan efek samping dan interaksi obat tradisional dengan obat lain/ makanan-minuman juga masih sangat rendah. Terbatasnya kapasitas promosi kesehatan di daerah dan kurangnya tenaga promosi kesehatan mengakibatkan tidak maksimalnya pelaksanaan promosi kesehatan dan pemberdayaan masyarakat, terutama tentang tanaman obat/obat tradisional di Dusun Pucung.

\section{Metode}

Salah satu program yang bisa diaplikasikan adalah pengikutsertaan perempuan di dalam bidang kesehatan adalah dengan pembentukan kader TAMAWA. Kader TAMAWA nantinya diharapkan bisa menjadi penggerak masyarakat untuk lebih bisa memanfaatkan tanaman obat/ obat tradisional secara benar dan aman. Beberapa warga Pucung mengalami efek samping penggunaan jamu/ obat tradisional yang mengakibatkan penyakit kronis (hipertensi dan gagal ginjal/ jantung). Hal ini salah satunya dikarenakan kurangnya pemahaman tentang aspek keamanan obat. World Health Organization (WHO) memperkirakan sekitar 4 biliun orang menggunakan obat tradisional (obat dari bahan alam) (Farnsworth et al, 1985). Di pasar global, pasar untuk obat tradisional diperkirakan mencapai US\$107 biliun pada tahun 2017 dengan pertumbuhan perdagangan internasional yang mengalami kenaikan sebesar $15 \%$ per tahun. Dengan adanya kenaikan perdagangan obat herbal, terjadi pula kenaikan dalam hal kemungkinan adanya pemalsuan (adulterasi) dan pencampuran dalam pembuatan obat herbal (Colombo et al, 2013). Sebagai contoh, Beberapa bahan kimia obat yang sering ditambahkan dalam jamu tersebut adalah dexamethason dan parasetamol yang khasiat dari dexamethason adalah analgetik dan antiradang kuat. Dexamethason sering mengakibatkan myopathy (otot menyusut dan nyeri) pada penggunaan oral, juga menekan adrenal agak kuat. Sedangkan efek samping parasetamol adalah kerusakan darah, kerusakan hati dan ginjal (Saputra, 2015).

Kegiatan pengabdian melibatkan berbagai pihak, diantaranya ketua RT, Kader PKK dari Dusun Pucung dan PSOH (Pusat Studi Obat Herbal) Jurusan Farmasi UII. Kegiatan diawali dengan melakukan diskusi dengan Ketua RT setempat untuk sosialisasi kegiatan yang akan dilakukan, selain itu juga menentukan lokasi penanaman tanaman obat (TOGA).

Kegiatan dilakukan selama 6 bulan dan terbagi dalam 3 tahap pelaksanaan. Bulan 1 dan 2 merupakan kegiatan sosialisasi dan survey yang dilakukan terkait dengan penggunaan tanaman sebagai pengobatan tradisional di Dusun Pucung. Selanjutnya pada tahap ini dibentuk kader TAMAWA yang beranggotakan kelompok PKK desa tersebut. Pada tahap ini terbentuknya kader TAMAWA sebanyak 4 orang di masing masing RT merupakan indikator terlaksanannya kegiatan.

Tahap kedua (bulan 3 dan 4), dilakukan pembuatan media promosi dalam bentuk brosur 
pemanfaatan tanaman obat. Pembuatan brosur melibatkan PSOH sebagai salah satu mitra kerjasama. Selain itu, pada tahap ini dilakukan pengadaan dan penanaman bibit TOGA hingga melakukan pelatihan pemanfaatan tanaman obat. Tahap akhir (bulan 5 dan 6), dilakukan kegiatan penyusunan buku pintar kader TAMAWA. Selain itu juga dibuat video informasi serta brosur tentang tanaman obat meliputi ciri, khasiat dan cara penggunaan yang selanjutnya diunggah di youtube.

\section{Hasil dan Pembahasan}

Kegiatan pengabdian masyarakat ini telah dilaksanakan dalam beberapa kegiatan diantaranya:

\section{Sosialisasi Program}

Tim pengabdian menghubungi mitra (dalam hal ini ketua RT 07) untuk perkenalan dan mendiskusikan teknis pelaksanaan pengabdian yang akan dilaksanakan. Proses ini dilaksanakan pada bulan April 2019.

\section{Pemberian informasi dan edukasi tentang TOGA dan obat tradisional}

Kegiatan ini dilaksanakan pada tanggal 26 Mei 2019 di rumah Ketua RT 07 dan mengundang perwakilan ibu-ibu PKK beserta mahasiswa dari PSOH UII. Pada kegiatan ini disampaikan mengenai jenis pengabdian yang akan dilaksanakan, pembentukan kader TAMAWA, dan disampaikan juga materi pengabdian masyarakat tentang TOGA da obat tradisional.

\section{Pendirian Kebun Tanaman Obat}

Kegiatan ini meliputi pembelian tanaman obat dari sentra koleksi tanaman obat di Kaliurang, pembuatan media tanaman dan penyiapan lokasi untuk kebun TOGA.

Beberapa jenis tanaman yang dibudidayakan dan fungsinya adalah:

1. Jintan (Carum carvi); sebagai penghasil minyak atsiri, antibakteri, bumbu masak

2. Daun seribu (Achillea millefolium); untuk obat nyeri haid dan sakit perut

3. Daun sendok (Plantago major); sebagai anti bakteri, antiinflamasi, obat bengkak, obat garal, dan obat terkilir,

4. Temu mangga (Curcuma amada); untuk obat bengkak, sakit perut, dan obat kanker

5. Temulawak (Curcuma xanthorrhiza); sebagai hepatoprotektor (mencegah penyakit hati), menurunkan kadar kolesterol, anti inflamasi anti radang), laxative (pencahar), diuretik (peluruh kencing), dan menghilangkan nyeri sendi- Manfaat lainnya yaitu, meningkatkan nafsu makan, melancarkan ASI, dan membersihkan darah

6. Zodia (Evodia suaveolens); untuk mengusir nyamuk

7. Keji beling (Strobilanthes crispa); sebagai obat diabetes, diuretik, dan antioksidan

8. Dandang gendhis (Clinacanthus nutans); sebagai antioksidan, antiinflamasi, dan obat herpes

9. Lavender (Lavandula officinalis); pengusir nyamuk dan antioksidan

10. Prasman (Ayapana triplinervis); peluruh kencing (diuretik), penambah nafsu makan, pereda demam (antipiretik), penghenti perdarahan (hemostatis) dan obat batuk (antitusif).

11. Brotowali (Tinospora crispa); obat hepatitis, diabetes, kanker, dan penambah nafsu makan

12. Purwoceng (Pimpinella pruatjan); sebagai afrodisiak

13. Sirih (Piper betle); seabgai antioksidan antibakteri, anti jamur, penghilang bau mulut, sariawan, dan obat eksim

14. Sirih merah (Piper orantum); anti TBC, obat batuk, antibakteri, anti jamur, obat eksim, dan obat keputihan

15. Kumis kucing (Orthosipon aristatus); untuk peluruh kencing, obat rematik, radang ginjal, batu ginjal, kencing manis, syphilis, diabetes

16. Melati (Jasminum); obat demam, digigit serangga, menurunkan kolesterol dan berat badan, sakit mata, dan sesak napas

17. Legundi (Vitex trifolia) obat batuk, obat shma, obat TBC, dan pengusir nyamuk

18. Daruju (Acanthus ilicifolius); sebagai obat cacing, hepatitis, anti kanker, dan obat batuk

Tanaman tersebut selanjutnya ditanaman bersama-sama dengan ibu-ibu PKK seperti terlihat pada foto kegiatan di gambar 3.

Setiap bulan dilakukan kerja bakti untuk merawat kebun TOGA tersebut yang dikoordinir oleh ibu-ibu PKK. Dalam tahap selanjutnya, bimbingan terkait dengan pemanfaatan kebun TOGA tersebut dilakukan melalui pembuatan buku pintar TOGA, pembuatan brosur TOGA/obat tradisional, dan pembuatan video informasi untuk 
obat tradisional/ tanaman obat dan penggunaannya melalui youtube dan juga disebarkan melalui whatsapp group ibu-ibu PKK.

Link video youtube dapat dilihat pada link berikut:

https://www.youtube.com/watch?v=DQkuC1RG9R $\underline{8 \& \mathrm{t}=6 \mathrm{~s}}$

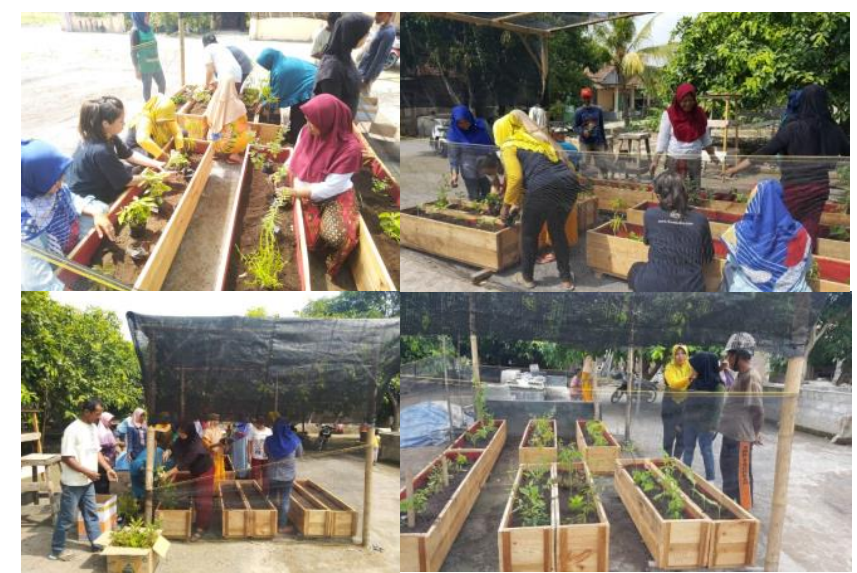

Gambar 3. Pembuatan kebun TOGA

\section{Kesimpulan}

Kegiatan pengabdian masyarakat ini mendapat sambutan yang baik dari Mitra Dusun Pucung-Kranggan II. Kebun tanaman obat yang dibangun juga telah dimanfaatkan oleh warga untuk mengatasi masalah kesehatan ringan. Media informasi yang diberikan berupa video dan brosur telah dimanfaatkan dan hendaknya diperbanyak mengingat di era pandemic COVID-19 kegiatan tatap muka langsung dengan mitra tidak dapat dilaksanakan. Setiap semester tim pengabdian dan PSOH UII meninjau dan memberikan bimbingan kepada mitra penabdian untuk menjamin keberlangsungan program pengabdian.

\section{Ucapan Terima Kasih}

Ucapan terima kasih ditujukan kepada DPPM UII yang telah membiayai kegiatan pengabdian masyarakat ini.

\section{Daftar Pustaka}

Bappenas, UU No 17 Tahun 2007 Tentang Rencana Pembangunan Jangka Panjang Nasional Tahun 2005-2025, 2007

Colombo ML, Pinorini aria T and Conti A (2013)
Internet Natural Product Trade, Business, and Risk of Damaged and/or Contaminated Products. In: K. R and JM. M (eds) natural products. Springer Berlin Heidelberg, 286299.

Farnsworth NR, Akerele O, Bingel A. S, Soejarto DD and Guo Z (1985) Medicinal plants in therapy. Bulletin of the World Health Organization 63(6): 965-981.

KeMenkes RI (2016) Permenkes No 9 tahun 2016 Tentang Upaya Pengembangan Keshatan Tradisional Melalui Asuhan Mandiri Pemanfaatan Tanaman Obat Keluarga dan Keterampilan. (879): 2004-2006.

KeMenKes RI (2017) Rencana Strategis Kementerian Kesehatan Tahun 2015-2019 (Revisi I-2017).

WHO, Preamble to the Constitution of WHO, 1948 